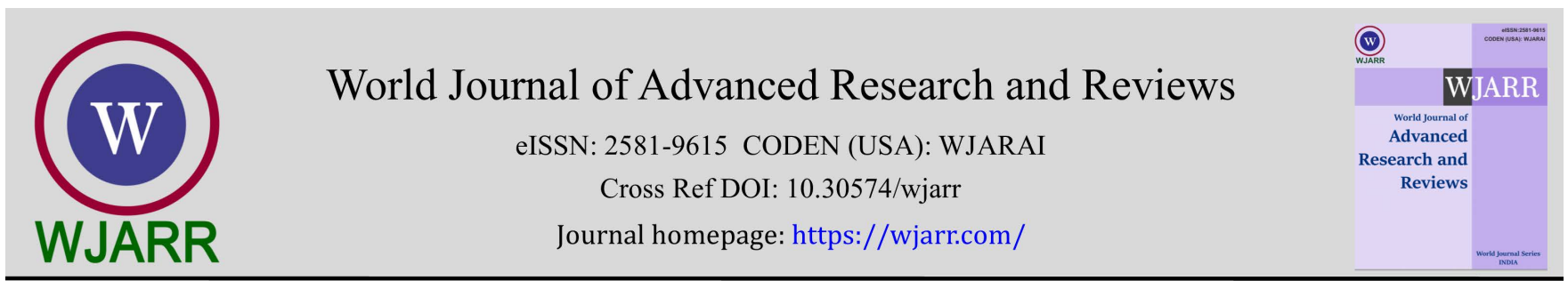

(RESEARCH ARTICLE)

\title{
Assessment of stakeholder's attitude towards intelligence gathering and use in the security of oil and gas operations in the Niger delta region
}

\author{
Agbeyi Monday ${ }^{*}$ and Onyige Chioma \\ Department of Sociology, University of Port Harcourt, Nigeria.
}

World Journal of Advanced Research and Reviews, 2022, 13(02), 433-437

Publication history: Received on 14 January 2022; revised on 18 February 2022; accepted on 20 February 2022

Article DOI: https://doi.org/10.30574/wjarr.2022.13.2.0166

\begin{abstract}
The study examined stakeholder's attitude towards intelligence gathering and use in the security of Oil and Gas operations in the Niger Delta Region. The study made us of 340 respondents which comprised of private security surveillance contractors, staff of Security department in oil companies, Managers in the selected oil companies and finally Government security personnel attached to oil companies and host community leaders across the selected Sates for the study. The study made use of questionnaire as the source of date on a five point Likert scale of Agree, Strongly Agree, Undecided, Disagree and Strongly Disagree. Key informant's interviews were also conducted. The study found that those stakeholders have a positive attitude towards intelligence gathering and its use in the security of oil and gas operation in the Niger Delta region. Hence it recommended that Oil and gas companies should display more transparency in their dealings with host communities in order to establish a robust communication network for gathering intelligence and preventing any damage to oil and gas installations.
\end{abstract}

Keywords: Assessment; Stakeholders; Attitude; Intelligence Gathering; Security; Oil; Gas

\section{Introduction}

Nigeria is a mono-economy. For much of her nationhood, the country has depended on revenue from the sale of oil and its products to run the wheel of nation-building. Since 1970, the country has earned at least $\$ 300$ billion from energy development and in 2019 a total of N4.6 trillion from Petroleum Profit Tax (PPT) and Royalties with about $37,070,000,000$ barrels of proven oil reserves as of 2016 , ranking 10 th in the world and accounting for about $2.2 \%$ of the world's total oil reserves of $1,650,585,140,000$ barrels. Nigeria has proven reserves equivalent to 237.3 times its annual consumption [1]. It currently produces 2.4 million barrels of oil per day, which constitutes about $90 \%$ of the government's revenue and 95\% of the country's foreign exchange earnings [2]. Nigeria is West Africa's biggest producer of petroleum and the sixth largest supplier of oil in the world, thanks to oil from the Niger Delta. Oil wealth has been instrumental to Nigeria's emergence as a leading player in world and regional politics.

The reality that the Niger Delta has been fundamental for the economic and administrative sustenance of the entire nation has not translated to an improved standard of living for the people of the region. The sorry state of the people in the region has resulted to serious problems of insecurity. The reality of insecurity, safety and peaceful operation of oil and gas operations in the Niger Delta region is no longer a matter of debate as it has attracted global attention There is need for comprehensive legislation on oil pipeline security; the need to review relevant legislation providing for the security of oil pipelines in Nigeria; proper funding of the security agencies saddled with the overall responsibility for managing as well as safeguarding the pipelines to ensure their productivity; and overhauling the entire security apparatus put in place to protect oil pipelines in Nigeria by having a sustainable and strategic approach to dealing with oil pipeline insecurity [3]. This was further corroborated by [4] when he stated in his study that intelligence gathering

\footnotetext{
${ }^{*}$ Corresponding author: Agbeyi Monday

Department of Sociology, University of Port Harcourt, Nigeria.

Copyright $(2022$ Author(s) retain the copyright of this article. This article is published under the terms of the Creative Commons Attribution Liscense 4.0.
} 
and management has not been able to effectively support the conduct of security operation in Nigeria. This is because the impact of intelligence has not been significant for many reasons. From the study, it is clear that the intelligence community lacked the requisite technological platform to effectively support the conduct of security operations and this was because of lack of funding, lack of real time intelligence, lack of analytical skill, lack of ICT facilities and absence of technical collection means for which he concluded that there is need to provide real time intelligence; provide the needed analytical skills; get the necessary ICT facilities and adequate funding to acquire other technical collection systems to effectively support operations in the country.

Nevertheless, Nigeria has been tagged the country most plagued by oil theft among her contemporaries of Indonesia, Russia, Iraq and Mexico. Statistics of oil theft among these major oil-producing countries shows that Nigeria has lost as much as 2 million barrels at first half of 2019 and about 120,000 barrels was stolen per day [2]. This is a huge loss compared to a total theft of just 2,000 to 3,000 barrels per day in Mexico and Indonesia, respectively [5\}. Thus, oil theft and illegal bunkering activities in the Niger Delta pose a challenge that threatens the very foundation of the oil industry, and by extension, the Nigerian economy.

To further exacerbate the problem, there is a report by Transparency International (2019) that military officers and other law enforcement agencies have been accused as being directly involved in the process of oil theft and vandalism. The empirical studies have it that other researchers have investigated the incidence of pipeline vandalism, lack of adequate intelligence support to support security operations, oil theft militancy and general insecurity surrounding oil and gas operations especially in the Niger Delta region. What has been overlooked in the literature is the significance and need for a multi-sectoral intelligence gathering and management in the security of oil and gas facilities especially in the Niger Delta region. It is based on this knowledge gap that this study aims to investigate intelligence gathering and management, challenges and stakeholder's attitudes towards its use in the security of oil and gas operations in the Niger Delta Region.

\section{Methodology}

The population of the study comprises private security surveillance contractors, staff of Security department in oil companies, Managers in the selected oil companies and finally Government security personnel attached to oil companies and host community leaders across the selected Sates for the study. Given the fact that the study is centered on intelligence gathering, which is a security apparatus, confidentiality of the respondents was kept hence, purposive sampling technique was used to select 6 oil companies from the two states. 60 personnel from the security department of the oil companies, 20 managers in the selected oil companies, 30 host community leaders, 60 Private surveillance contractors and 170 personnel from Government security agencies (Police, Army, Navy, NSCDC, DSS) attached to the selected oil companies were sampled. In total, 340 respondents formed the sample population for this study.

The study utilized both primary and secondary data sources. The primary source is questionnaire which was divided into two sections. Section A consisting of demographic data such as, gender, religion, marital status, educational qualification and leadership position. Section B consists of four (4) open-ended questions and a thirty (30) item closed ended questions on a five point Likert scale of Agree, Strongly Agree, Undecided, Disagree and Strongly Disagree. Key informant's interviews were also conducted.

\section{Results and discussion}

\subsection{Socio-Demographic Characteristics of Respondents}

Table 1 Gender distribution of respondents

\begin{tabular}{|l|l|l|l|l|}
\hline & Frequency & Percent & Valid Percent & Cumulative Percent \\
\hline Male & 282 & 87.0 & 87.0 & 87.0 \\
\hline Female & 42 & 13.0 & 13.0 & 100.0 \\
\hline Total & 324 & 100.0 & 100.0 & \\
\hline
\end{tabular}

Table 1 shows the gender distribution of respondents, the result revealed that 282 (87.04) of the respondents were males, while 42 respondents representing $12.96 \%$ were females. 
Table 2 Marital distribution of respondents

\begin{tabular}{|l|c|c|c|c|}
\hline & Frequency & Percent & Valid Percent & Cumulative Percent \\
\hline Single & 51 & 15.7 & 16.0 & 16.0 \\
\hline Married & 259 & 79.9 & 81.4 & 97.5 \\
\hline Widower & 8 & 2.5 & 2.5 & 100.0 \\
\hline Total & 318 & 98.1 & 100.0 & \\
\hline Total & 324 & 100.0 & & \\
\hline
\end{tabular}

The result of the analysis as shown in table 2 on the marital status of respondents showed that 51 respondents, representing $16.04 \%$ of the total respondents were single, with 259 respondents representing $61.45 \%$ being married and only eight respondents representing $2.52 \%$ being widowed. This showed that majority of the respondents were married.

Table 3 Age distribution of respondents

\begin{tabular}{|c|c|c|c|c|c|}
\hline & & Frequency & Percent & Valid Percent & Cumulative Percent \\
\hline \multirow{5}{*}{ Valid } & $20-25$ & 31 & 9.6 & 10.9 & 10.9 \\
\hline & $30-35$ & 112 & 34.6 & 39.4 & 50.4 \\
\hline & $40-45$ & 89 & 27.5 & 31.3 & 81.7 \\
\hline & $45-50$ & 52 & 16.0 & 18.3 & 100.0 \\
\hline & Total & 284 & 87.7 & 100.0 & \\
\hline \multicolumn{2}{|l|}{ Total } & 324 & 100.0 & & \\
\hline
\end{tabular}

From the result shown in table 3 on the age of distribution of respondents, it was shown that 16 respondents, representing $16.67 \%$ were between $20-25$ years, with 43 respondents, representing $44.79 \%$ were between $30-35 \%$, with 30 respondents representing $31.25 \%$ being between $40-45$ years, while seven respondents, representing $7.29 \%$ were 50 years and above.

Table 4 Educational Qualification distribution of respondents

\begin{tabular}{|c|l|c|c|c|c|}
\hline \multicolumn{2}{|c|}{} & Frequency & Percent & Valid Percent & Cumulative Percent \\
\hline \multirow{4}{*}{ Valid } & Secondary & 101 & 31.2 & 31.6 & 31.6 \\
\cline { 2 - 6 } & HND/BSC & 159 & 49.1 & 49.7 & 81.3 \\
\cline { 2 - 6 } & Masters & 60 & 18.5 & 18.8 & 100.0 \\
\cline { 2 - 6 } & Total & 320 & 98.8 & 100.0 & \\
\hline \multicolumn{2}{|l|}{ Total } & 324 & 100.0 & & \\
\hline
\end{tabular}

From the result displayed in table 4 on the educational qualification of respondents, it is shown that 101 respondents representing $31.56 \%$ of respondents had secondary school qualification, with 159 respondents representing $49.69 \%$ had either HND/B.Sc qualification, with 60 respondents representing 18.75\% had a master's qualification. 
Table 5 Sector distribution of Respondents

\begin{tabular}{|l|c|c|c|c|}
\hline & Frequency & Percent & Valid Percent & Cumulative Percent \\
\hline Government & 166 & 51.2 & 51.2 & 51.2 \\
\hline Private & 73 & 22.5 & 22.5 & 73.8 \\
\hline Community & 85 & 26.2 & 26.2 & 100.0 \\
\hline Total & 324 & 100.0 & 100.0 & \\
\hline
\end{tabular}

Table 6 Mean analysis of attitude of stakeholders towards intelligence gathering and management of oil and gas operations

\begin{tabular}{|c|c|c|c|c|c|c|c|c|}
\hline $\mathbf{S} / \mathbf{N}$ & $\begin{array}{l}\text { Attitude of stakeholders towards Intelligence } \\
\text { Gathering }\end{array}$ & $\begin{array}{l}\text { SD } \\
(\%)\end{array}$ & $\begin{array}{l}\text { D } \\
(\%)\end{array}$ & $\begin{array}{l}\text { UD } \\
(\%)\end{array}$ & $\begin{array}{c}\text { A } \\
(\%)\end{array}$ & $\begin{array}{l}\text { SA } \\
(\%)\end{array}$ & $\begin{array}{c}\text { Mean } \\
(\text { SD) }\end{array}$ & Remarks \\
\hline 1 & $\begin{array}{l}\text { Stakeholders are interested in intelligence } \\
\text { gathering and monitoring activities when there are } \\
\text { direct specific material benefit accruing to them as } \\
\text { a result of their involvement. }\end{array}$ & $\begin{array}{c}0 \\
(0.0)\end{array}$ & $\begin{array}{c}94 \\
(29.0)\end{array}$ & $\begin{array}{c}14 \\
(4.3)\end{array}$ & $\begin{array}{c}168 \\
(51.9)\end{array}$ & $\begin{array}{c}48 \\
(14.8)\end{array}$ & $\begin{array}{c}3.52 \\
(1.06)\end{array}$ & Agreed \\
\hline 2 & $\begin{array}{l}\text { Being interested in intelligence gathering and } \\
\text { management is worthwhile because it contributes } \\
\text { to the development and success of the industry } \\
\text { which is important for the development of the } \\
\text { society. }\end{array}$ & $\begin{array}{c}24 \\
(7.4)\end{array}$ & $\begin{array}{c}0 \\
(0.0)\end{array}$ & $\begin{array}{c}34 \\
(10.5)\end{array}$ & $\begin{array}{c}26 \\
(8.0)\end{array}$ & $\begin{array}{c}240 \\
(74.1)\end{array}$ & $\left|\begin{array}{c}4.41 \\
(1.15)\end{array}\right|$ & Agreed \\
\hline 3 & $\begin{array}{l}\text { Community members and stakeholders should be } \\
\text { interested in getting involved in intelligence } \\
\text { gathering because it allows the industry to achieve } \\
\text { its functions for the benefit of society. }\end{array}$ & $\begin{array}{c}0 \\
(0.0)\end{array}$ & $\begin{array}{c}18 \\
(5.6)\end{array}$ & $\begin{array}{c}12 \\
(3.7)\end{array}$ & $\begin{array}{c}147 \\
(45.4)\end{array}$ & $\begin{array}{c}147 \\
(45.4)\end{array}$ & $\left|\begin{array}{c}4.30 \\
0.78\end{array}\right|$ & Agreed \\
\hline 4 & $\begin{array}{l}\text { Not all Stakeholders should be involved in } \\
\text { intelligence gathering and management because it } \\
\text { is the private business of the company and they are } \\
\text { there to make profit. }\end{array}$ & $\begin{array}{c}82 \\
(25.3)\end{array}$ & $\begin{array}{c}156 \\
(48.1)\end{array}$ & $\begin{array}{c}7 \\
(2.2)\end{array}$ & $\begin{array}{c}15 \\
(4.6)\end{array}$ & $\begin{array}{c}64 \\
(19.8)\end{array}$ & $\left|\begin{array}{c}2.54 \\
(1.42)\end{array}\right|$ & Disagreed \\
\hline 5 & $\begin{array}{l}\text { I will be willing to contribute to or be involved } \\
\text { intelligence gathering and management as it } \\
\text { ensures the security of oil and gas operation for } \\
\text { the benefit of our community. }\end{array}$ & $\begin{array}{c}0 \\
(0.0)\end{array}$ & $\begin{array}{c}7 \\
(2.2)\end{array}$ & $\begin{array}{c}3 \\
(0.9)\end{array}$ & $\begin{array}{c}134 \\
(41.4)\end{array}$ & $\begin{array}{c}180 \\
(55.6)\end{array}$ & $\left|\begin{array}{c}4.50 \\
(0.63)\end{array}\right|$ & Agreed \\
\hline 6 & $\begin{array}{l}\text { Every stakeholder should be interested and should } \\
\text { be involved in intelligence gathering and } \\
\text { management because it is useful for the } \\
\text { sustenance of the industry and development for } \\
\text { our economy and society. }\end{array}$ & $\begin{array}{c}3 \\
(0.9)\end{array}$ & $\begin{array}{c}18 \\
(5.6)\end{array}$ & $\begin{array}{c}45 \\
(13.9)\end{array}$ & $\begin{array}{c}142 \\
(43.8)\end{array}$ & $\begin{array}{c}116 \\
(35.6)\end{array}$ & $\begin{array}{c}4.08 \\
(0.89)\end{array}$ & Agreed \\
\hline 7 & $\begin{array}{l}\text { Only those who are direct beneficiaries of the } \\
\text { activities of company should be involved in } \\
\text { intelligence gathering and monitoring and should } \\
\text { not be the business of every stakeholders. }\end{array}$ & $\begin{array}{c}104 \\
(32.1)\end{array}$ & $\begin{array}{c}68 \\
(21.0)\end{array}$ & $\begin{array}{c}19 \\
(5.9)\end{array}$ & $\begin{array}{c}91 \\
(28.1)\end{array}$ & $\begin{array}{c}42 \\
(13.0)\end{array}$ & $\begin{array}{c}2.68 \\
(1.48)\end{array}$ & Disagreed \\
\hline 8 & $\begin{array}{l}\text { Oil companies should not expect other stake } \\
\text { holders to be involved in intelligence gathering } \\
\text { because it not their business }\end{array}$ & $\begin{array}{c}128 \\
(39.5)\end{array}$ & $\begin{array}{c}117 \\
(36.1)\end{array}$ & $\begin{array}{c}47 \\
(14.5)\end{array}$ & $\begin{array}{c}15 \\
(4.6)\end{array}$ & $\begin{array}{c}17 \\
(5.2)\end{array}$ & $\begin{array}{c}2.00 \\
(1.09)\end{array}$ & Disagreed \\
\hline & Aggregate Mean & & & & & & 3.49 & Agreed \\
\hline
\end{tabular}


From the result displayed in table 6 on the sector distribution of respondents, it was shown that 166 respondents representing $51.23 \%$ were from the government or public sector, while 73 respondents which represent $22.53 \%$ of respondents were from the private sector and 85 respondents which represented 26.23\% were from the communityrelated sector. This result therefore suggest that majority of the respondents were government workers or were publicly employed.

Based on the result shown in table 6 on the attitude of stakeholders towards intelligence gathering and its use in the security of oil and gas operations in the Niger Delta Region, it was shown that all items had a mean ratings greater than 3.00 which is the criterion mean of the study, with the exception of item 4 (Not all Stakeholders should be involved in intelligence gathering and management because it is the private business of the company because they are there to make profit) with a mean of 2.54 (SD = 1.42), item 7 (Only those who are direct beneficiaries of the activities of company should be involved in intelligence gathering and monitoring and should not be the business of every stakeholders) with a mean rating of 2.68 ( $\mathrm{SD}=1.48$ ), and item 8 (Oil companies should not expect other stake holder to be involved in intelligence gathering because it not their business) with a mean rating of 2.00 (SD $=1.09)$. From the reported mean ratings, item 5 had the highest mean of 4.50 (SD = 0.63), while item 8 had the least mean rating of $2.00(S D=1.09)$. From the aggregate mean rating of 3.49, it therefore implies that stakeholders have a positive attitude towards intelligence gathering and its use in the security of oil and gas operation in the Niger Delta region.

\section{Conclusion}

This study addressed the attitude of stakeholders towards intelligence gathering and its use in the security of oil and gas operations in the Niger Delta region, it was shown that stakeholders have a positive attitude towards intelligence gathering and its use in the security of oil and gas operation in the Niger Delta Region. According to the findings it was shown that stakeholders are interested in intelligence gathering and monitoring activities when there are direct specific material benefit accruing to them as a result of their involvement. Also, it was also agreed that every stakeholder should be interested and should be involved in intelligence gathering and management because it is useful of the sustenance of the industry and development of our economy and society. Furthermore, majority of the respondents agreed that they will be willing to contribute to or be involved intelligence gathering and management as it ensures the security of oil and gas operation for the benefit of our community.

The study further recommended that Oil and gas companies should display more transparency in their dealings with host communities in order to establish a robust communication network for gathering intelligence and preventing any damage to oil and gas installations.

\section{Compliance with ethical standards}

\section{Acknowledgments}

The authors wish to acknowledge the research assistants who assisted in the data collection procedure.

\section{Disclosure of conflict of interest}

There is no conflict of interest.

\section{Statement of informed consent}

For this study consent was sought from the respondents who freely consented to participating in the study.

\section{References}

[1] Central Bank of Nigeria Annual Report. 2019.

[2] Nigerian National Petroleum Company (NNPC) Annual Report. 2019.

[3] Amalachukwu 0, Ayobami O. Legal and Institutional Framework for promoting Oil Pipeline Security in Nigeria, Journal of sust. Dev. Law \& policy. 2017; 8: 2.

[4] Nte ND. Post Modern Wars and the Challenges of Counter Insurgency: Issues and Perspectives. 2013.

Dalby ER. Insecurity in Nigeria: Political, religious and cultural implications. Journal of Philosophy, Culture and Religion. 2014; 5: 1-7. 